\title{
SMARCA1 Gene
}

National Cancer Institute

\section{Source}

National Cancer Institute. SMARCA1 Gene. NCI Thesaurus. Code C19884.

This gene is involved in chromatin remodeling and regulation of transcription. 